\title{
Assessment of Building Greenhouse Gas Emissions Based on Hybrid Life-cycle Model
}

\author{
Zeng Deheng ${ }^{1,2, a}$, Ren Hong ${ }^{1, b}$ \\ ${ }^{1}$ Faculty of Construction Management and Real Estate, Chongqing University, \\ Chongqing China 400030 \\ ${ }^{2}$ Modern Project Management Research Center of Chongqing University \\ Chongqing China 400030 \\ azengdeheng@cqu.edu.cn, ${ }^{\mathrm{b}}$ renhong@cqu.edu.cn
}

Keywords: Greenhouse gas emissions; building life cycle; Economic Input-Output

\begin{abstract}
This paper constructs the building's hybrid life cycle model based on the traditional LCA model and EIO model, and uses it to measure and calculate GHG (Greenhouse Gas) emissions from buildings. This model divides the building life cycle into three stages, including materialization, utilization and dismantling. EIO model is used to calculate GHG indirect emissions, and LCA model is used to calculate GHG direct emissions. This method can be applied to effectively make use of the existing project cost data for calculation, thus overcoming the disadvantage of much workload arising from the traditional method. According to the calculation of one residential housing and comparison with the calculation result of LCA model, GHG emissions of this house are most serious in the stage of utilization; and in materialization stage, GHG emissions rely on the control over the emissions of upstream sectors and improvement of utilization efficiency of the applied materials. This model is able to provide new theoretical reference for the building GHG emissions.
\end{abstract}

\section{Introduction}

Man-made GHG emission is an important reason of global climate warming. The building industry consumed $40 \%$ of the world energy and discharged $36 \%$ of CO2. [1] The carbon emissions of all countries in the world are maintained around 1/3 of the total emissions. For example, building emissions of European Union (EU) in 2002 accounted for 13\%, belonging to the fourth major emission source of EU; the emissions of residential building and personal traffic in the United States are $49 \%$ of the social emissions [1]; annual emissions of Chinese buildings in current stage reached $28 \%$ of total social emissions [2], and total emissions of $\mathrm{CO} 2$ account for $40 \%$ of the total social emissions [3]. In order to realize the Copenhagen emission reduction target of Chinese government, it is imperative to reduce the building's carbon emissions. However, regarding the method for measuring the building's carbon emissions, many countries in the world, such as America, Germany and the United Kingdom, have formulated their own measurement methods, but there is not one internationally general and recognized standard yet. [4] Therefore, researching the building's total life cycle carbon emissions will be of great guiding significance for the government's emission reduction decision and the carbon transactions in the future.

\section{Reference Review}

At present, major measurement models of the building's carbon emissions include whole-process life cycle assessment model (LCA) and environmental input-output model (EIO, also known as industrial correlation model). LCA model, including total life cycle and environmental emissions model established by Zhu Yan [5] and other persons, potentiality influence model of the building's carbon emissions established by Zhang Zhihui [6], and Assessment Framework System of Carbon Reduction Technology of Green Low-carbon Residential Areas in China [7] are calculated by using the product of energy, material consumption and the corresponding carbon emissions factors in the relevant construction stages. Leif [8] and $\mathrm{Wu}$ [9] from foreign countries took houses and office 
buildings as objects respectively to research total carbon emissions in the life cycle. In the application of LCA model, although the researchers have slightly different emissions factor values and carbon solidification in the process of building material production, they have basically same calculation thinking, that is, specific inventory data and large quantity of labor and materials are required to estimate the carbon emissions of one building. For this reason, some scholars and institutions use EIO model to evaluate the building's carbon emissions. Japan used this model very early, its official research institution constructed Provincial Building Research Institute, Japan Promotion Association for Human and Environmental Symbiosis, and Architectural Institute of Japan, which adopted input-output method in 1990 to estimate the carbon emissions and materials and energy consumption in construction stage and trial stage, and formed the subsequent LCCO2 computing system[10][11]. And Shimizu Corporation, Kashima Corporation, Obayashi Corporation and other non-governmental institutions in Japan respectively established actuarial and rough estimate models with EIO model in the middle of 1920s, but the estimate system is not open to the public. China's Chen Guoqian [12] established ecological system measurement method and database for the building's carbon emissions according to 2007 Input-Output Table of China; Chang Yuan [13] calculated the building's chemical energy and pollution emissions according to 2002 Input-Output Table; and the research of Ji Junping [14] proved that $97.1 \%$ emissions of the building industry emissions were stemmed from other sectors rather than direct emissions.

Because the calculation theories of two models are different, when these two models are used to evaluate the same building, there will be distinct discrepancies between their measurement results. LCA model adopts direct consumption and carbon emissions factors of energy and materials as calculation basis, the building's production stage involves miscellaneous material kinds, each producer's actual energy consumption is not same and hard to be counted, and the consumption of some materials and energy is easy to be neglected, so such model calculation is very difficult. The theoretical foundation of EIO model is "GHG emissions of object rely on those of several objects, and the relied objects are related with infinite objects", indicating that, EIO model takes the entire system as research object, instead of single material or technology. However, this model can be only used to work out the average environmental load of the materials with certain industrial type, such as steel products, but cannot distinguish the environmental load of individual materials, such as reinforced bar and angle bar, and considered energy consumption of production equipment and other relevant materials, so the calculation result is usually bigger than that of LCA model. According to the statistical results of Japan, such as steel product category, the calculation result of EIO model was $1.111-1.287 \mathrm{~kg} \mathrm{CO} 2 / \mathrm{kg}$, and the measurement results of direct energy consumption showed that, section steel was $0.634-1.089 \mathrm{~kg} \mathrm{CO} 2 / \mathrm{kg}$, reinforced bar was $0.639-0.965 \mathrm{~kg} \mathrm{CO} 2 / \mathrm{kg}$, and steel plate was $1.599 \mathrm{~kg} \mathrm{CO} 2 / \mathrm{kg}$.

This paper tries to combine the advantages of EIO model and LCA model to establish hybrid evaluation model for counting the building GHG emissions, and reflect emissions level of Chinese buildings by using Chinese input-output table and emissions data. This model is applicable to the carbon emissions evaluation of residential houses, office buildings, commercial buildings and other kinds of new buildings, which can be utilized to evaluate the building life stages, estimate the direct emissions and indirect emissions, and make comparative analysis for the existing measurement model results.

\section{Research Method}

\section{Life cycle framework of building}

LCA refers to the analysis of environmental impact of one product in production, utilization, rejection and recycling stages, including energy utilization, resource consumption and pollutant emissions [15]. LCA contains 4 parts, which are respectively target and scope definition, inventory analysis, impact evaluation and result interpretation. In this paper, the boundary of building system includes building materialization, utilization and dismantling processes (See Fig. 1).

Greenhouse gas emissions of the building life cycle researched and counted this time contain direct emissions and indirect emissions (see Fig. 1). The building's direct emissions refer to the 
emissions generated during production and utilization, mainly including energy combustion in the building's materials production, construction, operation, and maintenance and dismantling stages; indirect emissions refer to the emissions generated by production chain sectors during the building materials production, construction and operation, namely, the sum of emissions in all upstream stages.

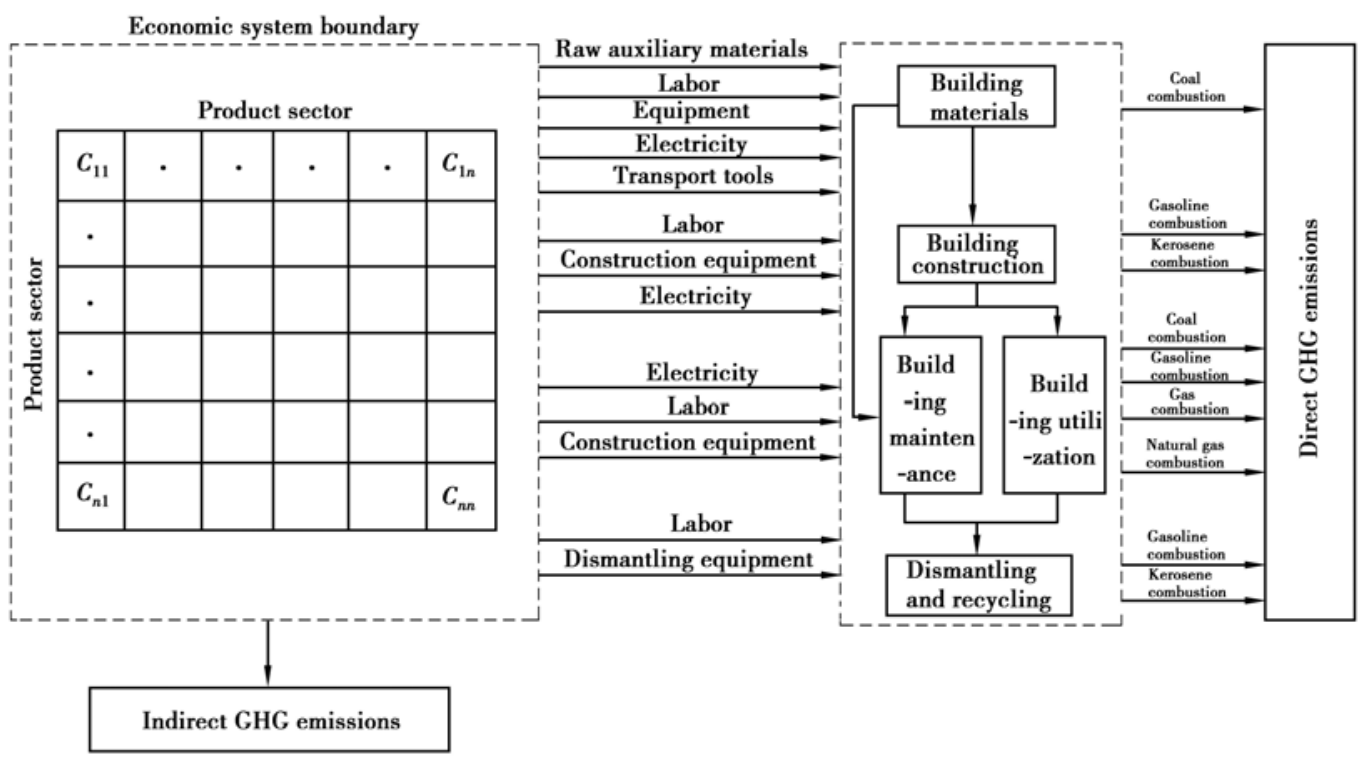

Fig.1 Direct and indirect emissions in the building life cycle

\section{EIO (ecological input-output) model}

Leontief [16] proposed EIO model for the first time in 1970 and used it in the research of industrial pollution emissions. Proops[17] analyzed CO2 emissions and control program selection with IO method. Vaze [18] calculated British EIO counting and forecasting. Chinese Li Li [19], Lei Ming [20] and Huang Xueliang [21] developed the research on resources - environment and energy - environment based on this model. This paper adopts the ecological input-output model proposed by Chen Guoqian[12], the basic hypotheses are: national economy sectors have direct proportion relationship between input and output; all equipment used for product production and service supply can be classified into certain particular sector; the calculate result indicates the environmental impact generated product production and service supply meeting the sector's final demand; import products and local products have the same environmental impact intensity. This model reformed the traditional economic input-output table, and put GHG emissions into consideration to obtain EIO table [22].

According to ecological input-output table, the ecological economic system contains $\mathrm{n}$ sectors and considers $\mathrm{m}$ kinds of GHG emissions can be represented as matrix form:

$$
F+\varepsilon X=\varepsilon Y
$$

Where, F means net GHG emissions matrix, X means economic input-output matrix, Y means local output matrix, and $\varepsilon$ means GHG emissions intensity. Then GHG emissions intensity matrix can be indicated as:

$$
\varepsilon=F(Y-X)^{-1}
$$

Lead in unit output value direct GHG emissions intensity and technological and economic matrix A, as follows:

$$
\begin{aligned}
& f=F Y^{-1} \\
& \begin{array}{l}
A=X Y^{-1} \\
\text { Then Expression (2) can be rewritten as: } \\
\quad \varepsilon=f(I-A)^{-1}
\end{array}
\end{aligned}
$$

Where $I$ is unit matrix, Expression $(I-A)^{-1}$ is called Leontief inverse matrix. This model only 
needs to multiply GHG emissions intensity of any product by the corresponding flow to get the GHG emissions reflected by this object.

Modeling concept of ecological input-output model is from top to bottom. The model takes national economy as system boundary, which contains the product's entire upstream stages, reflects the interrelation among economic sectors, and belongs to one measurement method on the basis of system theory. What should be emphasized is that, this model can only reflect the product's emission situation before final utilization and rejection stages, which is one effective indirect emissions measurement tool, but the direct emissions in final utilization and rejection stages should be calculate additionally. In addition, this method can only reflect the impact of production and demand in a particular year on emissions, but cannot embody the cross-year impact of production and demand on the pollutant emissions. So two disposal methods can be used, first, multiply the intensity of this year by direct emissions intensity change factor; second, multiply the intensity of this year by currency purchasing power factor. This paper adopts the second method for data disposal.

\section{Hybrid life cycle assessment of building}

Hybrid life cycle is to integrate LCA and EIO within one framework, which reserves pertinent calculation of LCA for direct emissions of fossil fuel, and effectively utilizes EIO model as well to reduce input of labor and materials during calculation and more effectively estimate the quantity of indirect emissions. According to the division of direct and indirect emissions, the building GHG emissions can be represented as:

$$
\begin{aligned}
& G H G_{L}=G H G_{E I O}+G H G_{P} \\
& G H G_{E I O}=\sum C I_{i} \times C T P_{i} \\
& G H G_{p}=\sum E F_{j} \times E_{j}
\end{aligned}
$$

$G H G_{L}, G H G_{E I O}, G H G_{P}$ respectively mean total GHG emissions of the building's total life cycle, indirect GHG emissions calculated with EIO, and direct GHG emissions calculated with LCA. $C_{i}$ means the building's GHG emissions intensity corresponds to No. $i$ labor, materials and equipment in all stages; and $C T P_{i}$ means comprehensive total price corresponds to No. $i$ labor, materials and equipment. This data can be obtained from project settlement data and daily payment account of the building. $E F_{j}$ means carbon emissions factor of No. $j$ common energy, and $E_{j}$ means different energy kind.

According to the building life cycle stage, GHG emissions can be divided into materialization, utilization and dismantling stages, and the GHG emissions in all stages are respectively indicated with $G H G_{L}, G H G_{O}$ and $G H G_{D}$.

$G H G_{L}=G H G_{L}+G H G_{O}+G H G_{D}$

In the building's materialization stage, $G H G_{L}$ includes two major emission processes of building materials and building construction. Building materials can be achieved by multiplying GHG emissions intensity worked out with EIO model by price of building materials in the list of quantities. Kerosene, gasoline and other direct emissions during construction can be calculated according to energy GHG emissions factor determined in National Guidelines for National Greenhouse Gas Emission Inventories published by Intergovernmental Panel on Climate Change (IPCC); and labor and machinery can be obtained from GHG emissions intensity, which is got by multiplying comprehensive unit price of labor and machinery in the list of quantities by EIO.

In the stage of the building's utilization, $G H G_{O}$ consists of building maintenance and building operation. Emission calculation method of building maintenance and construction is same. Building operation mainly includes direct emissions caused by gasoline, kerosene, fire coal, gas and natural gas for building heating, cooking and air conditioning, as well as indirect emissions arising from building electricity, water and property management.

$G H G_{D}$ in the stage of building dismantling is composed of building dismantling and construction waste disposal. The calculation method of GHG emissions in dismantling stage is as same as that of building construction process. In theory, construction disposal needs to consider that, part of building materials enter recycling process and have not been buried, so building recovery 
coefficient $\delta$ should be set. However, China still stays in the stage of low-level utilization of construction garbage ${ }^{[23]}$, mainly recovers the building's steel products and part of building blocks, and the recovery proportion is not same in different places, so recovery coefficient $\delta$ can be determined according to the local actual situation.

\section{Parameter Calculations}

\section{Data source}

The calculation core of indirect emissions is the calculation of sector carbon emissions intensity. In accordance with input-output tables of 135 sectors published by the National Bureau of Statistics in 2007 and direct GHG emissions data of that year in China1, this paper uses EIO model to work out the national-level GHG emissions intensity ( $t / 10,000 \mathrm{RMB})$. The total GHG in this paper is indicated with $\mathrm{CO} 2$-eq, which is the $\mathrm{CO} 2$ equivalent 2 after conversion of $\mathrm{CH} 4$ and $\mathrm{N} 2 \mathrm{O}$.

The calculation core of direct emissions is the determination of fossil fuel carbon emissions factor. The release institutions of emissions factor mainly include IPCC, DOE/EIA (Department of Energy of the United States), IEEJ (Institute of Energy Economics Japan), Energy Research Institute of NDRC and Chinese Academy of Engineering (CAE). This paper mainly collects the emission factors of coal, gasoline, kerosene, diesel, gas and liquefied petroleum gas in relation to the building's direct emissions.

\section{Main parameter}

Parameters of direct emissions. Through collection of carbon emissions factors of main energy made by domestic and foreign research institutions, direct emissions factors caused by building energy consumption are as shown in the following Table 1. In order to guarantee the uniformity of energy emissions results, this paper suggests using the emission factors of IPCC Guidelines for National Greenhouse Gas Emission Inventories for calculation.

Table 1 Carbon emissions factor of main energy in building life cycle

\begin{tabular}{|c|c|c|}
\hline Energy Type & Release Institution & $\begin{array}{l}\text { Emission Factor/ }(\mathrm{kg} \\
\left.\quad\left[\mathrm{CO}_{2}\right) \cdot \mathrm{kg}^{-1}\right]\end{array}$ \\
\hline \multirow{5}{*}{$\mathrm{Coal}^{3}$} & $\begin{array}{l}\text { IPCC Guidelines for National Greenhouse } \\
\text { Gas Inventories }\end{array}$ & 2.772 \\
\hline & DOE/EIA & 2.574 \\
\hline & IEEJ & 2.772 \\
\hline & Energy Research Institute of NDRC & 2.741 \\
\hline & CAE & 2.493 \\
\hline Gasoline & $\begin{array}{l}\text { IPCC Guidelines for National Greenhouse } \\
\text { Gas Inventories }\end{array}$ & 2.031 \\
\hline Kerosene & $\begin{array}{l}\text { IPCC Guidelines for National Greenhouse } \\
\text { Gas Inventories }\end{array}$ & 2.095 \\
\hline Diesel & $\begin{array}{l}\text { IPCC Guidelines for National Greenhouse } \\
\text { Gas Inventories }\end{array}$ & 2.171 \\
\hline $\begin{array}{c}\text { Liquefied } \\
\text { petroleum gas }\end{array}$ & $\begin{array}{l}\text { IPCC Guidelines for National Greenhouse } \\
\text { Gas Inventories }\end{array}$ & 1.849 \\
\hline Coke oven gas & $\begin{array}{l}\text { IPCC Guidelines for National Greenhouse } \\
\text { Gas Inventories }\end{array}$ & 1.301 \\
\hline Natural gas & $\begin{array}{l}\text { IPCC Guidelines for National Greenhouse } \\
\text { Gas Inventories }\end{array}$ & 1.644 \\
\hline
\end{tabular}

There are two calculation modes for direct emissions during transport, first, measure and calculate according to transport tool and the actual transport distance; second, measure and calculate according to average transport distance after statistical analysis. In order to simply the calculation, this paper adopts the second method. According to the analysis of Chinese freight composition, average transport distance of main building materials and GHG emissions coefficients of different

\footnotetext{
1 This data is estimated according to energy balance sheet of China of current year and the calculation method of IPCC Guidelines for National Greenhouse Gas Inventories. The specific calculation process is as shown in Reference [12].

2 This equivalent is converted by using the proportion of $\mathrm{CO}_{2}: \mathrm{CH}_{4}: \mathrm{N}_{2} \mathrm{O}=1: 31: 210$ in global warming potential program (GWP).

3 "Coal" called in this Table is raw coal and washed coal referred in IPCC Inventories.
} 
transport modes are achieved (see Table 2, Table 3).

Table 2 the Average Transport Distance of Main Building Materials ${ }^{[24]}$

\begin{tabular}{|l|c|l|c|}
\hline Building Materials & $\begin{array}{c}\text { Transport } \\
\text { Distance[km] }\end{array}$ & Building Materials & $\begin{array}{c}\text { Transport } \\
\text { Distance[km] }\end{array}$ \\
\hline Sandstone & 200 & Glass & 100 \\
\hline Cement & 100 & Wood & 80 \\
\hline Steel products & 125 & Paint & 80 \\
\hline Walling & 60 & Nonmetallic minerals & 50 \\
\hline Ceramics & 105 & Concrete blocks & 50 \\
\hline
\end{tabular}

Table 3 the Emissions Coefficient of Different Transport Modes

\begin{tabular}{|l|c|}
\hline Transport Mode & $\begin{array}{c}\text { Greenhouse Gas Emissions Coefficient } \\
{[\mathrm{kg} / \mathrm{t} \cdot \mathrm{km}]}\end{array}$ \\
\hline $\begin{array}{l}\text { Railway (diesel } \\
\text { locomotive) }\end{array}$ & 0.239 \\
\hline Highway (gasoline) & 0.124 \\
\hline Highway (diesel) & 0.166 \\
\hline Inland water transport & 0.031 \\
\hline
\end{tabular}

Parameters of indirect emissions. According to direct GHG emissions data in China in 2007[12,14] and sectoral input-output tables of 135 sectors in 2007, it is possible to establish 2007 ecological input-output table, and work out GHG emissions intensity of each sector. The emissions intensity values related to buildings are as shown in Table 4. During calculation, it is allowable to multiply the emissions intensity provided in Table 2 by the corresponding materials, labor and other amounts to get the corresponding GHG emissions. The corresponding sectors of the common materials, equipment and labor during construction are as shown in Table 5.

Table 4 Sector Greenhouse Gas Emissions Intensity[t/10k RMB]

\begin{tabular}{|c|l|c|}
\hline Sector No. & \multicolumn{1}{|c|}{ Sector Name } & $\begin{array}{c}\text { Total Greenhouse Gas (GWP) } \\
{\left[\mathrm{t} \mathrm{CO}_{2}=\mathrm{eq} / \mathrm{t}\right]}\end{array}$ \\
\hline 009 & Mining-beneficiation industry of non-ferrous metal mines & $3.89 \mathrm{E}+00$ \\
\hline 010 & $\begin{array}{l}\text { Mining-beneficiation industry of nonmetallic mines and other } \\
\text { mines }\end{array}$ & $3.48 \mathrm{E}+00$ \\
\hline 027 & Bast fiber textile, tiffany textile and fine processing industry & $3.42 \mathrm{E}+00$ \\
\hline 032 & $\begin{array}{l}\text { Wood processing and wood, bamboo, rattan, palm and grass } \\
\text { product industry }\end{array}$ & $3.63 \mathrm{E}+00$ \\
\hline 034 & Papermaking and paper product industry & $3.60 \mathrm{E}+00$ \\
\hline 037 & Petroleum and nuclear fuel processing industry & $7.47 \mathrm{E}+00$ \\
\hline 042 & $\begin{array}{l}\text { Paint, printing ink, pigment and similar product manufacturing } \\
\text { industry }\end{array}$ & $5.37 \mathrm{E}+00$ \\
\hline 043 & Synthetic materials manufacturing industry & $5.95 \mathrm{E}+00$ \\
\hline 044 & Special chemical product manufacturing industry & $6.46 \mathrm{E}+00$ \\
\hline 047 & Chemical fiber manufacturing industry & $5.48 \mathrm{E}+00$ \\
\hline 048 & Rubber product industry & $4.40 \mathrm{E}+00$ \\
\hline 049 & Plastic product industry & $5.42 \mathrm{E}+00$ \\
\hline 050 & Cement, lime and gypsum manufacturing industry & $1.56 \mathrm{E}+01$ \\
\hline 051 & Cement and petroleum product manufacturing industry & $8.53 \mathrm{E}+00$ \\
\hline 052 & Tile, stone and other building materials manufacturing industry & $9.02 \mathrm{E}+00$ \\
\hline 053 & Glass and glass product manufacturing industry & $7.07 \mathrm{E}+00$ \\
\hline 054 & Ceramic product manufacturing industry & $5.62 \mathrm{E}+00$ \\
\hline 055 & Refractory materials product manufacturing industry & $5.97 \mathrm{E}+00$ \\
\hline 056 & $\begin{array}{l}\text { Graphite and other nonmetallic minerals product manufacturing } \\
\text { industry }\end{array}$ & $8.16 \mathrm{E}+00$ \\
\hline 059 & Steel rolling processing industry & $6.94 \mathrm{E}+00$ \\
\hline 062 & Non-ferrous metal rolling processing industry & $4.45 \mathrm{E}+00$ \\
\hline 063 & Metal product industry & $4.83 \mathrm{E}+00$ \\
\hline 064 & Boiler and prime motor manufacturing industry & $3.62 \mathrm{E}+00$ \\
\hline & & \\
\hline
\end{tabular}




\begin{tabular}{|l|l|c|}
\hline 065 & Metal processing machinery manufacturing industry & $3.77 \mathrm{E}+00$ \\
\hline 066 & Hoisting transport equipment manufacturing industry & $3.89 \mathrm{E}+00$ \\
\hline 067 & $\begin{array}{l}\text { Pump, valve, compressor and similar machinery manufacturing } \\
\text { industry }\end{array}$ & $4.11 \mathrm{E}+00$ \\
\hline 068 & Other universal equipment manufacturing industry & $4.09 \mathrm{E}+00$ \\
\hline 069 & $\begin{array}{l}\text { Mine, metallurgy, building's special equipment manufacturing } \\
\text { industry }\end{array}$ & $3.99 \mathrm{E}+00$ \\
\hline 070 & $\begin{array}{l}\text { Chemical industry, wood, nonmetal processing special equipment } \\
\text { manufacturing industry }\end{array}$ & $4.02 \mathrm{E}+00$ \\
\hline 072 & Other special equipment manufacturing industry & $3.79 \mathrm{E}+00$ \\
\hline 077 & Motor manufacturing industry & $3.54 \mathrm{E}+00$ \\
\hline 078 & $\begin{array}{l}\text { Power transmission and distribution and control equipment } \\
\text { manufacturing industry }\end{array}$ & $3.57 \mathrm{E}+00$ \\
\hline 079 & $\begin{array}{l}\text { Wire, cable, optical cable and electrical equipment manufacturing } \\
\text { industry }\end{array}$ & $3.84 \mathrm{E}+00$ \\
\hline 080 & $\begin{array}{l}\text { Home appliances and non-power implement manufacturing } \\
\text { industry }\end{array}$ & $3.36 \mathrm{E}+00$ \\
\hline 081 & Other electrical machinery and equipment manufacturing industry & $3.70 \mathrm{E}+00$ \\
\hline 082 & Communication equipment manufacturing industry & $2.81 \mathrm{E}+00$ \\
\hline 088 & Instrument and meter manufacturing industry & $2.99 \mathrm{E}+00$ \\
\hline 092 & Electric power and heating power production and supply industry & $1.26 \mathrm{E}+01$ \\
\hline 094 & Water production and supply industry & $3.60 \mathrm{E}+00$ \\
\hline 095 & Building industry & $4.88 \mathrm{E}+00$ \\
\hline 097 & Road transport industry & $2.45 \mathrm{E}+00$ \\
\hline 113 & Real estate industry & $5.30 \mathrm{E}-01$ \\
\hline
\end{tabular}

Table 5 Correspond sectors of the building materials, equipment, energy and labor ${ }^{1}$

\begin{tabular}{|l|c|l|c|}
\hline \multicolumn{1}{|c|}{ Items } & Sector No. & \multicolumn{1}{|c|}{ Items } & Sector No. \\
\hline Sandstone & 010 & Wire and cable & 079 \\
\hline Cement & 051 & Crane & 066 \\
\hline Wooden template & 032 & Valve, pump, heat pump & 067 \\
\hline Water & 094 & $\begin{array}{l}\text { Power transformation and } \\
\text { distribution equipment }\end{array}$ & 078 \\
\hline Building blocks, stone products & 052 & Air conditioner & 080 \\
\hline UPVC/PE/PB pipes & 049 & Boiler & 064 \\
\hline Glass & 053 & Labor (1) & 095 \\
\hline Electric power, heating power & 092 & Labor (2) & 113 \\
\hline $\begin{array}{l}\text { Floor tiles, sanitary fittings and } \\
\text { other ceramic products }\end{array}$ & 054 & Paint, preservative, adhesive & 042 \\
\hline $\begin{array}{l}\text { Reinforced bar, steel plate, } \\
\text { section steel, wire rod, steel } \\
\text { pipes }\end{array}$ & 059 & $\begin{array}{l}\text { Bulldozer, excavator, road roller, } \\
\text { mixing equipment }\end{array}$ & 069 \\
\hline
\end{tabular}

Note: Table 4 is emissions intensity in 2007. If emissions intensity of other years (after 2007) needs to be calculated, multiply currency purchasing power factor of the current year corresponding to 2007. 2008- 2011 currency purchasing power factors are as shown in Table 6.

Table 6 Annual purchasing power of money factor in China

\begin{tabular}{|c|c|}
\hline Year & Purchasing Power Factor \\
\hline 2008 & 0.941 \\
\hline 2009 & 0.948 \\
\hline 2010 & 0.916 \\
\hline 2011 & 0.867 \\
\hline
\end{tabular}

\section{Calculation Examples}

\footnotetext{
1 Labor (1) is the corresponding emission intensity during building construction, repair and dismantling. Labor (2) is the corresponding emission intensity of property management during operation.
} 


\section{Building information}

This paper selects one residential building of Shanghai as example. This building was established in 2009, having 5-storey reinforced bar concrete structure and total building area of $2831.28 \mathrm{~m}^{2}$. Other specific information is as shown in Reference [25]. Raw Reference has utilized LCA method to measure and calculate the carbon emissions of this building's total life cycle, and this paper measures and calculates the GHG emissions with hybrid life cycle method.

\section{Results and analysis of GHG emissions}

Gross GHG emissions GWP of this building is 4512.13t, and annual emissions of unit area is $31.88 \mathrm{~kg}$, it is about 1.36 times (gross $3,223 \mathrm{t}$, unit area year $22.8 \mathrm{~kg}$ ) as much as the original calculation result through comparison with the original result. The first reason is that the original calculation only considered $\mathrm{CO} 2$ emissions, without considering emissions of $\mathrm{CH} 4$ and $\mathrm{NO} 2$; and the second one is the calculation results arising from EIO model are generally higher that those of LCA calculation.

As shown in Fig. 2, according to the distribution of this building's total life cycle emissions, the building's operation stage contributed the most emissions, $87.3 \%$ of total emissions, the second is building materialization stage, accounting for $11.4 \%$, and the least is building dismantling stage, only accounting for $1.3 \%$. It can be found through analysis of direct and indirect emissions proportion in different stages that, the direct emissions proportion in building materialization 1 is only $4.9 \%$, similar to the research result of Ji Junping[14] (97.1\%), because upstream nonmetallic minerals production, metal rolling and electric power sectors generate GHG emissions in quantity, this also proves that, controlling emissions of upstream building materials production sector and improving utilization efficiency of building materials will have important significance for emission reduction in the process of materialization. In building operation stage, this building is hot in summer and cold in winter, without heating requirement in winter, and its indirect emissions are mainly from power utilization, with proportion of $89 \%$, indicating that taking necessary building energy conservation measures and reducing energy consumption will cause direct impact on building operation stage. In building dismantling stage, this paper fails to consider construction waste recycling, so it is calculated with direct dismantling and burial method.

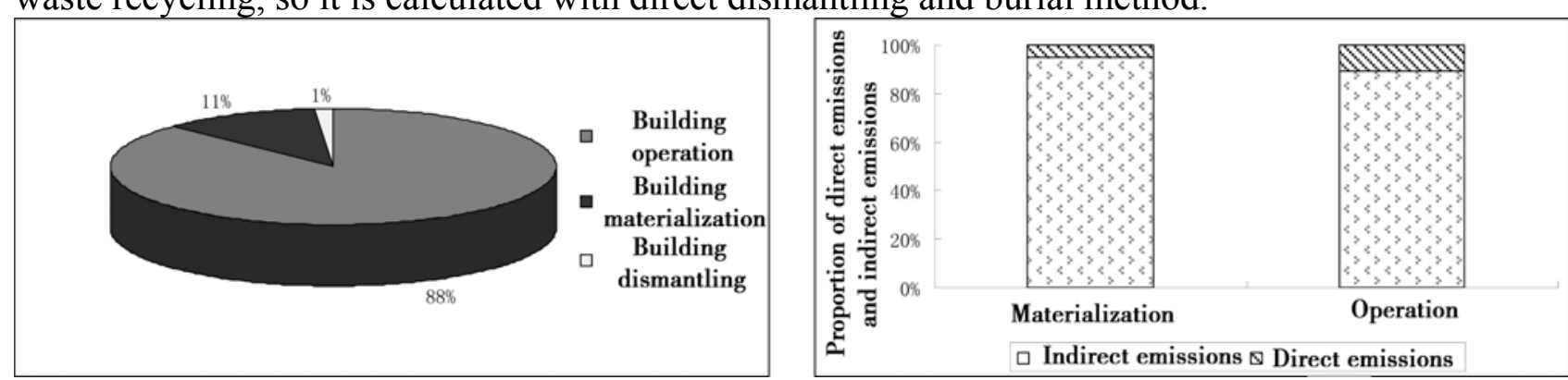

Fig. 2 Greenhouse Gas Emissions Distribution in Example

\section{Conclusions}

Buildings are the important source of GHG emissions, so it is of great significance to control the building's GHG emissions. This paper combines EIO and LCA methods and applies hybrid life cycle model to analyze and measure the GHG emissions of the building's total life cycle, and establish relevant mathematic model. This model has put the building's direct emissions and indirect emissions into consideration to calculate building emissions according to materialization, operation and dismantling stages. This model is able to systematically quantify the building GHG emissions, thus avoiding the disadvantages of the traditional LCA model, such as much data required, large quantity of calculation and truncation error, effectively utilizing the existing project price data and daily energy consumption data, and reducing input of labor and materials during accounting.

According to the analysis of the actual case conducted with this model, we can find that the key

${ }^{1}$ Because building material production and building industry belong to different sectors, this paper puts emissions of building materials during production in indirect emissions for calculation. 
to the building GHG emissions is to control emissions in operation stage, especially reduce the building's energy consumption. Major control point in the building materialization stage is emission level of upstream materials production sectors. In the present stage, selecting reasonable building materials to improve the utilization efficiency of building materials can reduce the level of GHG emissions to certain extent. In the current stage, because dismantling stage only accounts for the relatively small proportion, its impact on the building's emissions can be temporarily ignored.

\section{Acknowledgements}

This research was supported by National Social Sciences Funds Project (No.11CJY040), General Program of Ministry of Housing and Urban-Rural Development of the People's Republic of China (No.2020809920090156). This work was also supported by Project of Colleges and Universities Funds Subsidy for Youth of the Central Government.

\section{References}

[1] Yu P, Ma X.Review on Studies of Life Cycle Carbon Emission from Residential Buildings. Building Science, Vol.27 (2011), p. 9-11.

[2] Shang C. Quantitative Assessment on Carbon Emission of Different Structures in Building Life Cycle. Building Science, Vol.27 (2011), p. 66-68.

[3] Cai X. Carbon Emissions Analysis and Energy Conservation Emission Reduction Measures for Residential Buildings. Journal of Disaster Prevention and Mitigation Engineering, Vol.30 (2010), p. 419.

[4] Information on http://www.chinagb.net/cabee/news/20120425/85833.shtml.

[5] Zhu Y. Life-cycle Energy Consumption and Environmental Emissions Model In Residential Buildings . Journal of Tsinghua University: Natural Science, Vol.50 (2010), p. 326-328..

[6] Zhang Z. Carbon Emissions Evaluation of the Building Life Cycle. Construction Economy, Vol.2 (2010), p. 45.

[7] China Federation of Industry and Commerce, Discussion Draft Excerpt of Carbon Reduction Technology Assessment System of China's Green Low-carbon Residential Areas. Edited by Jingrui (China) Real Estate Research Institute. Eco-city and Green Building. Vol.1 (2010), p. 30-33.

[8] Leif Gustavsson. Anna Joelsson. Roger Sathre. Life cycle primary energy use and carbon emission of an eight-storey wood-framed apartment building . Energy and Buildings, Vol.42 (2010), p. 230-242.

[9] Huijun J. Wu \& Zengwei W. Yuan \& Ling Zhang \& Jun Bi, Life cycle energy consumption and CO2 emission of an office building in China . Life Cycle Assess, Vol.17 (2012), p. 105-118.

[10] Information on http://www.aij.or.jp.

[11] Information on http://www.mlit.go.jp.

[12] Chen G.Q. Measurement Method of Building Carbon Emissions System. Chapter, 2,Beijing Xinhua Publishers, (2010).

[13] Chang Y, Wang Y. Analysis of Building Embodied Energy and Atmosphere Impacts in China Based on Economic Input-Output Life-Cycle Assessment Model. China Civil Engineering Journal. Vol.44 (2011), p. 137-139.

[14] Ji J. Greenhouse Gas Emissions by Chinese Economy: An Assessment Based on EIO-LCA Model. Journal of Peking University: Natural Science, Vol.47 (2011), p. 742-744.

[15] Environmental manage lift cycle assessment principles and framework. ISO, 1997.

[16] W. Leontief. Environmental repercussions and the economic structure: an input-output approach . The review of economics and statistics, Vol.52 3(1970), p. 262-271.

[17] Elizabeth Symons. John Proops. Philip Gay. Carbon-dioxide production by the UK economy: An input-output assessment . Applied Energy, Vol.15(1994), p. 19-43.

[18] Prabhat Vaze. An Economic Analysis of Tenure in East Anglia Using Qualitative Data.Journal of Agricultural Economics, Vol.3(1998), p. 443-457. 
[19] Li L. Analyzing China's Energy Consumption and Environment Problems by Input-Output Method on Trial. Statistical Research, Vol.5 (1994), p. 32-33.

[20] Lei M. Green Input-output Accounting: Theory and Application. Peking University Press, (2000).

[21] Huang Xueliang. Optimal Control of Input-Output Model of Environment-Economy System. Chinese Journal of Management Science, Vol.2 (1997), p. 44-47.

[22] Chen G.Q.Low-carbon building assessment and multi-scale input-output analysis. Communications in Nonlinear Science and Numerical Simulation, Vol.16 (2011), p. 583-595.

[23] Sun Y. Recycling and Application of Construction Waste in China. The First Technical Seminar of International Intelligent and Green Buildings, Beijing, (2005).

[24] Zhu Y. Cases for Life-Cycle Energy Consumption and Environmental Emissions in Residential Buildings. Journal of Tsinghua University: Natural Science, Vol.50 (2010), p. 330-334..

[25] Li H. Computational Study on Life Cycle Carbon Emission of Residential Building in Shanghai. Urban Studies: The Seventh International Green Buildings and Building Energy Conservation Conference Proceedings, (2011). 